\title{
HUNTING GRUFFALO: ‘GANGS’, UNREASON, AND THE BIG BAD COALITION
}

"But who is this creature with terrible claws/And terrible teeth in its terrible jaws?/He has knobbly knees and turned out toes/And a poisonous wart on the end of his nose/His eyes are orange, his tongue is black/He has purple prickles all over his back/Oh help! Oh no! It's a Gruffalo!"

- Julia Donaldson, The Gruffalo (1999; London: Macmillan)

"Politicians must be allowed to panic. They need activity. It is their substitute for achievement."

"We don't measure our success by results but by activity".

- Sir Humphrey Appleby, Yes Minister (BBC/Jay \& Lynn, 1982: 'Open Government'; 'The Compassionate Society')

Youth violence, like most other forms of violence has been falling steadily in recent years. Despite - or perhaps because of this - recent policy responses have begun to rely increasingly on the spectre of 'the gang' as a trope for representing serious youth crime, invoking moral panic, and justifying greater police powers in socially marginalised communities. The cynical disconnect between this and the growing weight of critical, empirical British youth gang research strains belief and exposes the unreason at the heart of Coalition policy. In this post, we analyse last Friday's release of several reports relating to the 2011 policy paper 'Ending Gang and Youth Violence'. Amidst the rambling and turgid prose, we find a Government wasting $\mathrm{f} 10$ million on untheorised, unevidenced, and unevaluated 'activity' that risks reifying the very problem it claims to fear.

Along with two colleagues with a decade's worth of experience researching and problematising British youth gangs, I' last year criticised 'Ending Gang and Youth Violence' (hereafter EGYV) on three grounds. The first was evidential: it could not define and operationalize the 'gangs' it declared as its policy object; nor did it seem aware of the analysis ${ }^{\text {iii }}$ commissioned and published by an institutional co-author of the report - the Home Office - that both offered a definition and challenged its own simplistic elision of guns, gangs, and knife violence; nor did it seem aware of the general lack of a 'what works' evidence base for gang reduction, despite a century's worth of well-funded US research. The second criticism related to the indiscriminate 'blunderbuss' nature of the framed policy response: four government bills and sixty varied policy initiatives were adduced as being relevant, effective or promising on the basis of weak, anecdotal or non-existent evidence; and no commitment to robust evaluation was given for EGYC as a whole nor its several dozen recommended 'next steps'. Finally, intellectual/moral incoherence was evident as the paper simultaneously wielded a large and enhanced criminal justice 'stick' in one metaphorical hand while proffering a somewhat wrinkled 'carrot' of pre-announced and austerity-compromised welfare support in the other.

In short, the paper, launched in the febrile and disorientated aftermath of the 2011 riots, offered no evidence of understanding its principle object, a set of spasmodic responses based around deterrence and 'joined up working', and a small pot of money allocated to 'gang-affected' areas in which services of unknown and unknowable content, quality and impact were to be offered.

Two years on, our worst fears have been confirmed. The main 'Annual Report 2013' document ${ }^{\text {iv }}$ released last Friday repeats the confused/confusing 'blunderbuss' approach of the original paper: forty nine pages, sixty action points, dozens of initiatives - many of which are existing generic DWP or Home Office programmes - and, in lieu of real evidence of impact, six glib text boxes describing a small range of initiatives from the twenty-nine initial pilot sites. An accompanying 'Review 2012-13' document ${ }^{v}$ published simultaneously by the Home Office promises further detail of 'achievement' and 'success' (it studiously stays clear of the word 'evaluation') but only offers the following information:

1. that the only effort at direct evaluation was from the funders themselves (the Home Office), which amounted to (i) two online surveys of 'local contacts' - mostly community safety managers as opposed to service providers and (ii) up to three telephone interviews with the same contacts. Only 10/29 (34\%) completed both surveys, and $13 / 29$ (44.8\%) provided an interview. Six trial areas 'did not contribute to the research in any way' (p.6).

2. that the statutory and voluntary organisations that were possibly heavily dependent on the EGYV funding were reported to perceive the experience of being funded as broadly positive, though (a) the initial procurement and assessment arrangements took so long that little time was available to use the money, and (b) there were fears concerning the sustainability of funding. No individual or organisational measures of gang-involvement or offending behaviour were recorded. 
3. that due to the perceived impossibility of an actually eminently-achievable mixed methods (quasi-)experimental evaluation of project inputs, processes and outcomes, the Home Office instead elected to examine police recorded youth crime in project areas over 2012-13. It found that most forms of youth violence fell to the same extent that they had fallen in the year preceding EGYV and, indeed, in most other communities in England \& Wales.

To be clear, the weaknesses of the 'evaluation design' are such that if it were an undergraduate research methods project, it would barely pass, and would certainly fail at postgraduate level.

Despite this, both Teresa May and lain Duncan Smith make Orwellian claims of success in the ministerial foreword to the main document: "The initiative is working, the crimes that the programme aims to tackle are diminishing... the programme has led to more effective leadership and a greater sense of strategic direction. That has helped those on the front-line increase the effectiveness of their work. And that has contributed to the drop in youth violence" (p.6). The first and last clause of this quote are in no way supported by the available data, and in that sense, should be seen as an outright lie designed to mislead.

Most damningly, the review uses the terms 'gang' no less than 266 times, which also features in many further initiatives, including - incredibly - the intention to provide gang 'fact packs' and 'warning sign' training documentation to police and a range of educational, community and criminal justice organisations. But there remains no clear, evidence-based operational definition of a 'gang' that can be measured or used in any sense by any actor. The basis for applying the gang label or advancing a claim to understand the phenomenon sufficiently well to provide 'advice' to others is non-existent.

In sum, these reports are utterly appalling: in the era of austerity, $f 10$ million of taxpayers' money has been wasted on initiatives that have not been described or evaluated, and where grandiose success claims are made despite precisely no evidence of understanding or achievement. Seen in these terms, the Coalition's use of the term 'gang' can only be seen as a convenient rhetorical label for inciting public fear, scapegoating structural abandonment of and justifying increased controls over marginal populations, and for further stigmatising entire communities.

This contemptible state of affairs has added piquancy in relation to two robust criminological findings that the Home Office and DWP are no doubt unaware of. The first, is that public services that are perceived to be heavy-handed and procedurally unfair undermine their own functioning as people distrust and disengage from them ${ }^{\mathrm{vi}}$; the second is that clumsy imposition of the 'gang' label tends to increase group cohesion such that one calls into being the very problems and processes one was supposed to be guarding against ${ }^{\text {vii }}$.

In short, rather like the mouse in Julia Donaldson's feted children's book, the Coalition is in the process of creating its own Gruffalo; an imaginary monster designed to distract and get its author out of a tight fix. In this story, however, the Gruffalo is being fought, not with wit and imagination, but by a tediously complex mesh of rhetoric and overlapping social controls based on false premises and specious logic. The question yet to be resolved, however, is 'will the mouse still win out in the end, or itself be devoured'?

\footnotetext{
' HM Government (2011). Ending Gang and Youth Violence: A Cross Governmental Report including further evidence and good practice case studies. London: TSO

ii Shute J, Aldridge J, Medina J. "Loading the policy blunderbuss." Criminal Justice Matters 87, no. 1(2012) : 40-41

iii Sharp, C., Aldridge, J., and J. Medina. 2006. Delinquent youth groups and offending behaviour: findings from the 2004 Offending Crime and Justice Survey. London: Home Office.
}

${ }^{\text {iv } H M ~ G o v e r n m e n t ~(2013) . ~ E n d i n g ~ G a n g ~ a n d ~ Y o u t h ~ V i o l e n c e: ~ A n n u a l ~ R e p o r t ~ 2012-13 . ~ L o n d o n: ~ T S O . ~}$

${ }^{\vee}$ Home Office (2013). Ending Gang and Youth Violence: Review 2012-13. London: Home Office.

${ }^{v i}$ see, for example, the voluminous recent work of Jon Jackson, Ben Bradford \& Mike Hough on police legitimacy.

vii see the classic work of Malcolm Klein (1971) Street Gangs and Street Workers. Prentice Hall: Englewood Cliffs, CA. 